\title{
GREEN HERON PREYS UPON HUMMINGBIRDS
}

MICHAEL C. LONG, 6128 N. Reno Ave., Temple City, California 91780; mlongbird@gmail.com

KIMBALL L. GARRETT, Natural History Museum of Los Angeles County, Los Angeles, California 90007; kgarrett@nhm.org

On 5 February 2017, William Peebles photographed an adult Green Heron (Butorides virescens) capturing two separate hummingbirds at the Los Angeles County Arboretum in Arcadia, Los Angeles Co., California. The encounter took place at the waterfall created in the south-central portion of the grounds. Peebles' written description of the encounter is paraphrased in this note.

As Peebles approached the waterfall, he noticed a Green Heron standing on top of the falls. The heron seemed preoccupied, and Peebles noticed that several hummingbirds seemed to be harassing it. He watched for a minute or so and noted a hummingbird hovering a few feet in front of the heron. The heron, clearly agitated, twisted its head to follow the hummingbirds as they flew around it. To obtain a closer view Peebles moved to a position above the falls. There he immediately noticed that the heron had captured an Anna's Hummingbird (Calypte anna) by the tail (Figure 1 ), though he did not witness the actual capture. The hummingbird escaped this encounter with the heron. Peebles repositioned himself to get closer and found that the heron had captured a second hummingbird, this time an Allen's (Selasphorus sasin). Again he did not witness the capture, but photographed the event until the heron had completely swallowed the hummingbird (Figure 2).

Davis and Kushlan (1994) did not mention birds among the foods reported for the Green Heron in the primary literature on the species. A photo by James E.

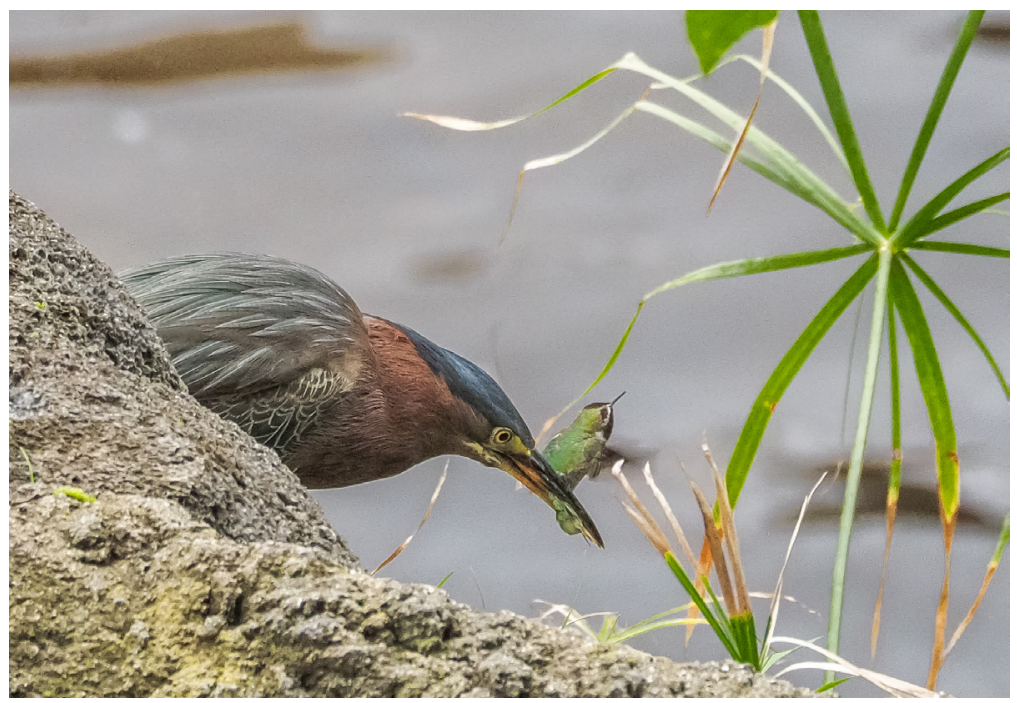

Figure 1. Green Heron capturing an Anna's Hummingbird, which escaped, Los Angeles County Arboretum, Arcadia, California, on 5 February 2017.

Photo by William Peebles 


\section{NOTES}

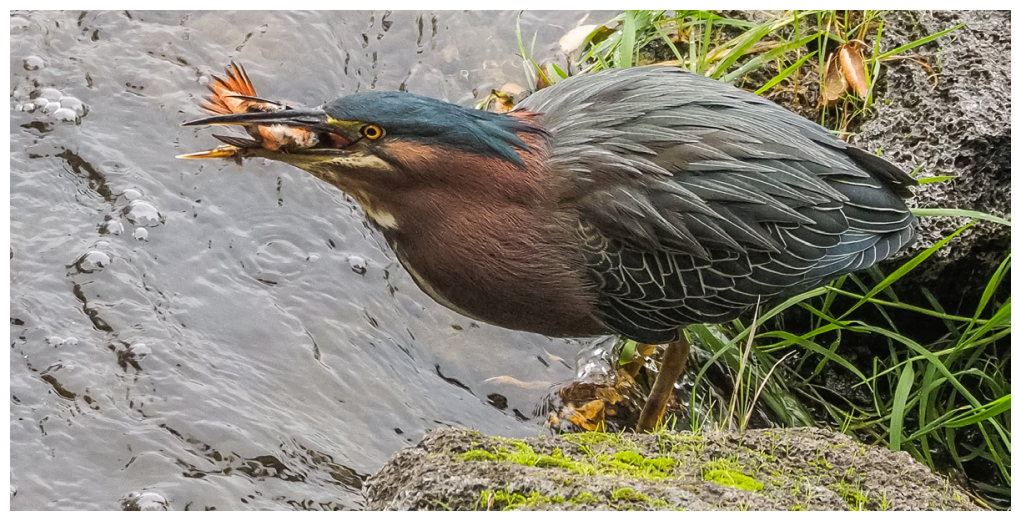

Figure 2. The same Green Heron capturing and consuming an Allen's Hummingbird.

Photo by William Peebles

Zabriskie (accompanied by Marcy Scott) taken near Radium Springs, Doña Ana Co., New Mexico, on 4 June 2006 shows an adult Green Heron with a female Blackchinned Hummingbird (Archilochus alexandri) in its bill [North American Birds 60: 597, 2006]. Another Green Heron fed on nestlings of the Village Weaver (Ploceus cucullatus) in the Dominican Republic (Wiley 2001). Stocker (1994) reported a Striated Heron (Butorides striata), a close relative of the Green Heron, preying on a Red-billed Quelea (Quelea quelea) at the Victoria Falls in Zimbabwe, Africa; that heron repeatedly wetted its prey before swallowing it, a behavior not observed with the Green Heron at the Los Angeles arboretum. According to Moran (2010) a Lava Heron (Butorides [striata] sundevalli), another close relative, captured a Small Ground Finch (Geospiza fuliginosa) on Española Island in the Galapagos Archipelago on 24 May 2003. We thus report here one of the few records of a Butorides heron taking birds, and only the second such case involving the Green Heron or involving hummingbird prey. Nonetheless, the Green Heron is known for innovative foraging behavior, including the use of bait and tools. Whether the Green Heron at the Los Angeles County Arboretum was actively hunting hummingbirds or reacting aggressively to harassment by the hummingbirds is uncertain.

We thank Lou Orr for bringing this interesting observation to our attention and William Peebles for providing the photos and description of the encounter. John F. Garrett and Greg B. P. Davies provided details of important references. Reviews by Doug Faulkner, Steven Mlodinow, and Philip Unitt improved the draft.

\section{LITERATURE CITED}

Davis, W. E., Jr., and Kushlan, J. A. 1994. Green Heron (Butorides virescens), in The Birds of North America (A. Poole and F. Gill, eds.), no. 129. Acad. Nat. Sci., Philadelphia; doi 10.2173/bna.129.

Moran, M. D. 2010. Predation by a Lava Heron (Butorides striata sundevalli) on a Small Ground Finch (Geospiza fuliginosa) in the Galapagos Islands. Waterbirds 33:258-259; doi 10.1675/063.033.0216.

Stocker, R. 1994. Green-backed Heron preying on Quelea. Honeyguide 40:247.

Wiley, J. W. 2001. Green Heron (Butorides virescens) predation at Village Weaver (Ploceus cucullatus) nests. El Pitirre 14:130-133. 